DOI https://doi.org/10.18551/rjoas.2021-02.07

\title{
THE READINESS OF RICE FARMERS IN MALANG TO UTILIZE FINANCIAL TECHNOLOGY (FINTECH)
}

\author{
Paikoh E. ${ }^{*}$, Wisynu A.G., Destyana E.P., Dian I.P. \\ Faculty of Agriculture, University of Brawijaya, Malang, Indonesia \\ ${ }^{*}$ E-mail: pratiwi.fp@ub.ac.id \\ ORCID: 0000-0002-6104-431X
}

\begin{abstract}
Financial technology (fintech) is known as a kind of IT-based financial innovation that facilitate any transaction processes, including transfer, purchasing, and lending. Even if fintech also offers many advantages in farming business process, but seems like Indonesian farmers have a weak enthusiasm in utilizing this system. This research was aimed to measure readiness of rice farmers in applying fintech. This research was held in Malang as one of producer area of rice in East Java. Samples were chosen from farmers in Singosari district. Primary data was collected from 105 respondents in total, and was analyzed used structural equation modelling-partial least square (SEM-PLS) method. The results showed that only variables of Economic benefits $(\mathrm{ME})$, Convenience $(\mathrm{C})$, and Model of offered fintech (MF), whose path coefficient values are $0.20 ; 0.15$; and 0.73 respectively.
\end{abstract}

\section{KEY WORDS}

Farmer readiness, Fintech, Modelling-Partial Least Square.

At over $65 \%$ of farmers' empowerment programs, the failure rate of both government and Non-Government Organization/NGO farmingprojects is quite high and cannot be accounted for. Starting from the disbursement of funds, technical innovation of agriculture, non-performing loans. Government policy fertilizer subsidies to farmers are not able to improve the welfare of farmers due to the lack of coordination at the implementation level. It can be recognized that kind of helo and attention given by the stakeholders in the form of fertilizer subsidies, capital, and technology is highly problematic during implementation (Sunarminto, 2015).

According to Mulyaqin and Haryani (2015), the narrow land control will be difficult for farmers to access capital resources, when credit is needed for production purposes, daily basis before the harvest crops sold, and other social gatherings. In addition, due to mastery of the narrow land, farmers cannot meet the cost of living from one season to another without lending because the need for wage costs are expensive and employment opportunities outside the growing season is limited. So, credit has become part of life and agricultural economy. Therefore, if the credit is not available, the level of production and farming income will decrease drastically.

Long marketing channel is a problem that losses to farmers due to the income gap between the channel and the asymmetry of information concerning existing prices. According to Haryani (2013), the fundamental problems of marketing of paddy / rice are the long marketing channels and also the lack of information about prices received by the farmers. Farmers only receive information on the price of grain from fellow farmers and traders who immediately come to buy grain so that the asymmetry of information between the farmer and the final consumer is visible. It means that the fluctuations in the price of rice or grain due to the asymmetry of information likely to harm farmers and consumers but profitable for trader and rice grinder.

Problems in capital access and marketing chain length can be improved with existing technology that use financial technology (fintech) because it combines trading system with trading technology (Freedman, 2006). In addition, fintech can accelerate the purchase and sale transactions on different time and place. So, the buying and selling process can be 
conducted directly between producers and consumers which can shorten the marketing chain.

Therefore, it is important to do research in order to take advantage of the opportunity that fintech is able to improve the welfare of rice farmers in Malang Regency in terms of capital gains, minimize the losses due to long marketing chain, as well as the readiness in applying fintech. So, its implementation can be in line with farmers' expectation. The objectives of this research were: (1) to describe the implementation of fintech in Indonesia; (2) to measure the readiness of rice farmers in Malang in applying fintech; and (3) to determine the model required fintech farmers in Malang.

\section{LITERATURE REVIEW}

Financial Technology is concerned with building system that model, value, and process financial products such as bonds, stocks, contracts, and money. At minimum, financial products are represented by the dimention of price, time, and credit. Like commersial system, financial systems incorporate trading systems and trading technology to enable the buying and selling of products at different times and in different market spaces (Freedman, 2006; Wang, 2018).

Most of these banks are embracing financial technology (FinTech), due to the promise of its ability to generate new revenue streams, personalize offers, target cross-selling and improve customer services. These innovative financial technology companies, FinTechs, provide novel financial services; some of these start-ups have already grown to remarkable proportions like Alibaba, Amazon and Google. Although a common perception is that business models of FinTech companies focus on payment services and lending, they also encompass personal financial advisory services, crowdfunding, virtual currencies, InsurTech, RegTech, BigData and security (e.g. cyber security) (Stern et al., 2017; Stewart \& Jürjens, 2017).

Peer to Peer lending (P2P Lending) is a technology platform that digitally brings together borrowers (SMEs) who need business capital with lenders who expect competitive returns. P2P Lending has a unique advantage of being able to carry out interface functions through off-balance sheet funding. P2P Lending services are also more flexible and can allocate capital or funds to almost anyone, at any amount, effectively and transparently, and with low interest. The biggest Fintech players in Indonesia are payment and lending (Fintechnews Singapore, 2018; Wijaya, 2016).

The existence of Fintech opens greater opportunities for household consumers and the business world, including small and medium enterprises (SMEs) to access financial services. In addition, Fintech also offers convenience, speed of service, lower costs and convenience for consumers in enjoying financial services. The most important implications and dividends from the various benefits of Fintech are financial inclusion. This is expected to further promote sustainable economic growth and allow diversification of exposure to overall investment risk (Nizar, 2017).

The farmers' decision to adopt innovations is influenced by the certainty of the market for the products they produce, the need for innovation, and the availability of learning advice and credit facilities. An understanding of the factors that influence farmers 'decisions to implement innovations will provide an overview of the potential and readiness of farmers to apply agricultural technology, so that the technology introduced to farmers can be adapted to their own capacity and the capacity of farmers' resources. The low level of education by farmers causes the adoption of innovation to be relatively slower, due to the low level of cognitive and intellectual abilities. The younger farmers usually have greater enthusiasm and curiosity, so that the adoption of innovation is faster. (Amanah and Tjitropranoto, 2018; Andriani et al., 2018; Soekartawi, 2005).

There are three marketing channels in the distribution of rice marketing channels in Watugede Village, Singosari District, Malang Regency. The rice marketing channels are rice mills, wholesalers from Singosari District and Karangploso District, market traders, and Singosari District retailers and Karangploso District retailers. The system for determining 
prices in transactions utilizes a capital loan system from a milling level institution with a milling purchase system that uses an ijon system, superior information control so that the position of farmers does not have bargaining power and tends to be price recipients. Futhermore farmers get a small profit (Linawarti, 2015).

According to Ryu (2018), the research aims to understand why people are willing or unwilling to use Fintech and to determine whether the perceived beneficial effects and risk of continuing to Fintech depend on two types of users (early adopters and late adopters). The result of this study is that legal risk has the most negative effect on the intention to continue Fintech, while convenience has the strongest positive effect in continuing Fintech. Differences in specific benefits and predisposing risk factors were found between early adopters and late adopters. Early adopters are primarily focused on using Fintech on the efficiency of financial transactions, while late adopters are looking for more financial benefits through the use of Fintech. In addition, early adopters were concerned about legal risks, while late adopters considered security risks the most negative factor.

SEM (Structural Equation Modeling) is an analysis of latent variable equation systems models. Until now there have been several SEM analyzes using AMOS / LISREL software, PLS with SmartPLS software, GSCA with GeSCA and WarpPLS software. The choice of these two analysis models mainly depends on two things, namely the indicator model (outer model) and the relationship model between latent variables (inner model). However, covariance-based SEM analysis with AMOS and LISREL software, rule of thumb requires a relatively large sample, namely from 100 to 200. As for PLS, GSCA and WarpPLS it can be applied to small and large samples (Solimun et al., 2017).

\section{METHODS OF RESEARCH}

Quantitative approach was used in this research to determine the readiness of farmers in applying financial technology. This research was conducted in Singosari district which represented agricultural center areas with some basic considerations including agricultural land, the total population are farmers, or based on the amount of agricultural commodities production. The research was done in 2019.

Sampling determination technique used quota sampling, by determining the minimum number of respondents in each study site. In this research, the number of respondents at least 35 people at each location, so that the total respondents from three villages were 105 people. The minimum amount was based on the theory of "Central Limit" which stated that the data and number of population were close to normal distribution if the minimum amount to 30 samples (Anderson, et. Al., 2011). Selection of respondents in this study was done by assigning rice farmer respondents in accordance with the aim of this study was the readiness of farmers in applying fintech. So that, the respondents were farmers who owned land planted rice commodities, the harvest was sold as farm income, and farmers or their children had implemented as low as Fintech 1.0.

This research used primary data that were obtained from interviews with rice farmers and marketing agencies. Data were collected through interviews, observation and documentation.

Data were analyzed using descriptive and quantitative analysis techniques. Descriptive analysis was intended to describe readiness of rice farmers in applying fintech. Then, quantitative analysis was used to analyze the readiness of farmers in using fintech covering fintech models, economic benefit, unlimited transactions, convenience, and financial risk during fintech implementation. While quantitative analysis in this study used path analysis Structural Equation Modeling-Partial Least Square (SEM-PLS).

\section{RESULTS AND DISCUSSION}

The economic benefits in this research measured using three indicators, such as the level of capital requirements, the low cost in using fintech transaction, and the ease of marketing. Based on those three indicators, the low-cost indicator in using fintech transaction 
was the biggest indicator selected by respondents as a form of economic benefits offered by fintech. The value of low cost in using fintech transaction to the economic benefits was 0.887 from the loading factor shown in Table 1.

Table 1 - Cross Loading Value

\begin{tabular}{lllllll}
\hline Indicator & ME & TTB & KB & RK & MF & Information \\
\hline$X_{11}$ & $\mathbf{0 . 7 2}$ & -0.06 & -0.13 & -0.03 & -0.18 & Fulfilled \\
\hline$X_{12}$ & $\mathbf{0 . 8 8}$ & 0.08 & -0.00 & -0.08 & 0.20 & Fulfilled \\
\hline$X_{13}$ & $\mathbf{0 . 8 3}$ & -0.03 & 0.11 & 0.12 & -0.05 & Fulfilled \\
\hline$X_{21}$ & 0.13 & $\mathbf{0 . 8 1}$ & -0.03 & 0.10 & -0.08 & Fulfilled \\
\hline$X_{22}$ & -0.01 & $\mathbf{0 . 8 1}$ & -0.02 & -0.12 & -0.14 & Fulfilled \\
\hline$X_{23}$ & -0.07 & $\mathbf{0 . 8 5}$ & 0.04 & -0.19 & -0.00 & Fulfilled \\
\hline$X_{24}$ & -0.04 & $\mathbf{0 . 8 0}$ & 0.02 & 0.22 & 0.23 & Fulfilled \\
\hline$X_{31}$ & 0.10 & -0.18 & $\mathbf{0 . 8 1}$ & 0.05 & 0.10 & Fulfilled \\
\hline$X_{32}$ & -0.02 & 0.08 & $\mathbf{0 . 8 1}$ & 0.00 & 0.11 & Fulfilled \\
\hline$X_{33}$ & -0.09 & 0,11 & $\mathbf{0 . 7 3}$ & -0.07 & -0.24 & Fulfilled \\
\hline$X_{41}$ & -0.15 & 0.04 & -0.15 & $\mathbf{0 . 8 4}$ & -0.00 & Fulfilled \\
\hline$X_{42}$ & -0.05 & -0.26 & 0.22 & $\mathbf{0 . 8 6}$ & -0.04 & Fulfilled \\
\hline$X_{43}$ & 0.23 & 0.25 & -0.09 & $\mathbf{0 . 7 5}$ & 0.05 & Fulfilled \\
\hline$X_{51}$ & -0.07 & 0.01 & -0.06 & 0.17 & $\mathbf{0 . 8 1}$ & Fulfilled \\
\hline$X_{52}$ & -0.11 & 0.32 & 0.01 & -0.13 & $\mathbf{0 . 7 6}$ & Fulfilled \\
\hline$X_{53}$ & 0.27 & 0.01 & -0.30 & 0.008 & $\mathbf{0 . 8 3}$ & Fulfilled \\
\hline$X_{54}$ & -0.08 & -0.22 & 0.30 & 0.056 & $\mathbf{0 . 8 3}$ & Fulfilled \\
\hline$X_{55}$ & -0.01 & -0.10 & 0.05 & -0.11 & $\mathbf{0 . 7 9}$ & Fulfilled \\
\hline
\end{tabular}

Source: Primary Data Processed (2019).

These findings were consistent with the field research. Because of lending capital and product marketing could be done online without went to the bank or marketed directly the rice. According to Muzdalifa et al. (2018), fintech offered easy access to finance without high costs, thus reduced all kinds of obstacles in both price and non-price to the use of financial services by the public.

Table 2 - Square root Average Variance Extracted (AVE) Value

\begin{tabular}{lllllll}
\hline Indicator & ME & TTB & KB & RK & MF & Information \\
\hline EB & $\mathbf{0 . 8 1 9}$ & 0.663 & 0.558 & 0.577 & 0.335 & Fulfilled \\
UT & 0.663 & $\mathbf{0 . 8 2 3}$ & 0.620 & 0.642 & 0.305 & Fulfilled \\
C & 0.558 & 0.620 & $\mathbf{0 . 7 8 5}$ & 0.559 & 0.208 & Fulfilled \\
RF & 0.577 & 0.642 & 0.559 & $\mathbf{0 . 8 2 2}$ & 0.282 & Fulfilled \\
MF & 0.335 & 0.305 & 0.208 & 0.282 & $\mathbf{0 . 8 1 0}$ & Fulfilled \\
\hline
\end{tabular}

Source: Primary Data Processed (2019).

In this study, unlimited transactions were measured using four indicators, namely simple financial borrowing requirements, rapid financial transactions, unlimited capital lending, and price transparency. Indicator that was considered a form of unlimited transaction was indicator of unlimited capital lending. Viewed from the loading factor in table 5, the value of unlimited capital lending indicator was 0.855 . This indicated that the respondents saw unlimited transaction variables based on the unlimited amount of capital lending so that they could do the lending transaction as needed without restriction.

According Hapsari (2018), fintech's frequency of lending was high enough to help small businesses thrive. Respondents could take the advantage of this opportunity to create the rice community's profitable farming business and welfare in the research sites.

The convenience of transacting variable in this study was measured using three indicators of flexibility of time, location flexibility, and convenience in the transaction. Indicator which had the largest value seen from the loading factor was the flexibility of time with a value of 0812 shown in Table 5 . This indicated that respondents were ready to apply fintech when the time flexibility fulfilled because the capital needed could be directly disbursed and also selling the crops could be done online by using internet, so it would save time. 
According to Muzdalifa et al. (2018), a form of fintech strategy was everyone had access and full services from financial institutions namely on time, convenient, informative, and affordable, with full of respect for dignity, loans could be disbursed within less than a week, and loans could be done any time, not limited by time. In addition, the marketing was also not limited by time. The advantage offered by fintech was the convenience that made the respondents would have time flexibility in lending and marketing.

Financial risks were measured using three indicators of financial risks borne by investors, price fluctuations risk, and crop failure risk. The indicator with the largest value seen from the loading factor was price fluctuations risk in the amount of 0.869 shown in Table 1. The price fluctuations risk selected by the respondents because by using fintech the financial risk variable fluctuations in prices could be stabilized due to the transparency of prices provided in fintech. So, the respondents were not disadvantaged during the rice marketing.

Model of fintech offered was measured using five indicators of easy terms, allocation of flexible, ease to access data and information, leveling large and small businesses, and accessible to anyone. Based on those five indicators, the largest value seen from the loading factor was ease to access data and information with a value of 0839 as shown in Table 1. This indicator was of great concern to the respondents as it enabled access to marketing information data and selling price of rice and grain. Therefore, ease of access to data and information considered by the respondents because in fintech, they can easily access the data to figure out who was the investor or who was providing capital funds, so that information communicated transparently and clearly.

Farmers' readiness variable was measured using five indicators: basic personal finances, money management, debt and credit, savings and investment, and risk management. The indicator that showed the highest impact was basic personal finance with a value of 0.837 , followed by risk management of 0.806 , financial management of 0.791 , and asavings and investments of 0.730 . While in the lowest position was debt and credit indicator with a value of 0.650 . It showed that the increased readiness of respondents to use fintech must be supported by an improvement in basic personal finances which include several aspects, namely knowledge, attitudes, and also skills.

Based on the data presented in Table 3, the value of R-Square and Adj. R-square were 0.825 and 0.817 . This value had a powerful effect. According to Moore, Mccabe, and Craig (2009), if the R-square value $>0.7$ then the effect size was stronger. Adj. R-Square value 0.817 indicated that the Economic benefits (EB) variable, Unlimited Transactions (UT), Convenience (C), Financial Risks (FR), and Model of Fintech Offered (MF) had an effect of $81.7 \%$ on the Readiness on fintech (RF) variable, while the other $18.3 \%$ were influenced by variables outside the model.

Table 3 - R-square/Adjusted R-square

\begin{tabular}{lllllll}
\hline & $\mathrm{ME}$ & $\mathrm{TTB}$ & $\mathrm{K}$ & $\mathrm{RK}$ & $\mathrm{MF}$ & $\mathrm{KP}$ \\
\hline R-square & & & & & & 0.825 \\
$\begin{array}{l}\text { Adj. } \text { - } \text {-square } \\
\text { Chi-squared }\end{array}$ & & & & & & 0.817 \\
Full Collin VIF & 2.065 & 2.491 & 0.903 & 1.934 & 2.267 & 0.653 \\
\hline
\end{tabular}

Source: Primary Data Processed (2019).

Chi-squared value showed in Table 3 was 0.635 . Solimun et al. (2017) stated that Chisquared was used to assess the predictive validity or relevance of a set of latent predictor variables in variable creation. Models with predictive validity must have Chi-squared values higher than zero. The estimation results of the study showed a strong predictive validity as the value was above 0.35 . In this study, the full collinearity VIF value was $<3.3$ so that the criteria were met and according to Solimun et al. (2017), there was no vertical collinear problem. The value of VIP reached $<3,3$, so it could also be said there was no collinear problem in this study. 
Based on Table 4, the P-value on APC, ARS, and AARS was $<0.05$ or called significant. The APC, ARS, and AARS values were used to measure the average value of the path coefficient, R-square, Adjusted R-square in the model. The values of AVIF and AFVIF were used for testing the collinearity in SEM-PLS model, with the ideal criteria being $\leq$ 3.3. In this study, the value of AVIF and AFVIF was 3.3 or equal to 3,296 and 2,207, and it was said to be ideal. So, there was no vertical multicollinearity or lateral multicollinearity problems between indicators and between latent variables in this study.

Table 4 - Evaluation of Goodness of fit (GoF) Model

\begin{tabular}{llll}
\hline Indicator & Result & Standard Value & Information \\
\hline APC & $0.260 ; \mathrm{P}<0.001$ & $\mathrm{P}<0.05$ & Fulfilled \\
ARS & $0.825 ; \mathrm{P}<0.001$ & $\mathrm{P}<0.05$ & Fulfilled \\
AARS & $0.817 ; \mathrm{P}<0.001$ & $\mathrm{P}<0.05$ & Fulfilled \\
AVIF & 3.296 & $\leq 3.3$ & Ideal \\
AFVIF & 2.207 & $\leq 3.3$ & Ideal \\
GOF & 0.731 & Medium $\geq 0.25 ;$ large $\geq 0.36$ & Large \\
SPR & 1 & Acceptable $\geq 0.70 ;$ ideal $=1$ & Ideal \\
RSCR & 1 & Acceptable $\geq 0.90 ;$ ideal $=1$ & Ideal \\
SSR & 1 & $\geq 0.70$ & Fulfilled \\
NLBCDR & 1 & $\geq 0.70$ & Fulfilled \\
\hline
\end{tabular}

Source: Primary Data Processed (2019).

In the Table 4 , the GoF value showed a large value as $\geq 0.36$ was 0.731 , so the fit model was accepted in this study. The SPR and RSCR value were ideal because the result was one. The criteria of SPR and RSCR were accepted if $\geq 0.7$ and considered ideal if $=1$, while for RSCR were accepted if $\geq 0.9$ and considered ideal if $=1$. Ideally this value showed that there was no sympson's paradox problem in the model and this research model was free from the negative value of R-square.

The SSR value was achieved because it was either 1 or $\geq 0.7$. It showed that $100 \%$ of the path free model of statistical suppression. The last value measured in the GoF was the NLBCDR value. NLBCDR value has been stated to meet the criteria of $\geq 0.7$ which was 1 . It meant that $100 \%$ of the corresponding path in the model supported the hypothesis or there was no causality problem in the model.

Hypothesis testing was done by looking at the coefficient path on the model to discover the effect of direct relationship on one construct to another construct. Hypothesis testing was conducted by analyzing the value of the path coefficient and P-value. If the P-value $<0.05$ ( $\alpha$ $=5 \%)$ was obtained, the value was significant, so the hypothesis was accepted. However, if the $p$-value> $0.05(\alpha=5 \%)$, then the value was not significant, so the hypothesis was rejected.

Table 5 - Hypothesis Testing

\begin{tabular}{|c|c|c|c|}
\hline Hypothesis & Path coefficient & $p$-value & Information \\
\hline H1: Economic benefits affect significantly to Farmers' Readiness & 0.20 & 0.012 & Accepted \\
\hline H2: Unlimited Transactions significantly affect significantly to Farmers' Readiness & 0.13 & 0.074 & Rejected \\
\hline H3: Convenience affect significantly to Farmers' Readiness & 0.15 & 0.049 & Accepted \\
\hline H4: Financial Risks affect significantly to Farmers' Readiness & 0.09 & 0.173 & Rejected \\
\hline H5: Fintech Model Offered affect significantly to Farmers' Readiness & 0.73 & $<0.001$ & Accepted \\
\hline
\end{tabular}

Source: Primary Data Processed (2019).

Based on the results of the hypothesis analysis above, there were different influences from each variable. The description of the hypothesis testing variable was explained in the next subchapter.

Economic benefits had positive and significant impacts on farmers' readiness in applying fintech. The value of economic benefits influence on the readiness of rice farmers in applying fintech was 0.20 with a significance level of 0.012 . The result of analysis showed that the more positive economic benefits provided by fintech, the greater farmers' readiness in implementing fintech. As respondents, farmers needed economic benefits in farming and 
marketing their agricultural products and by using fintech, all of these activities could be done easily at low costs.

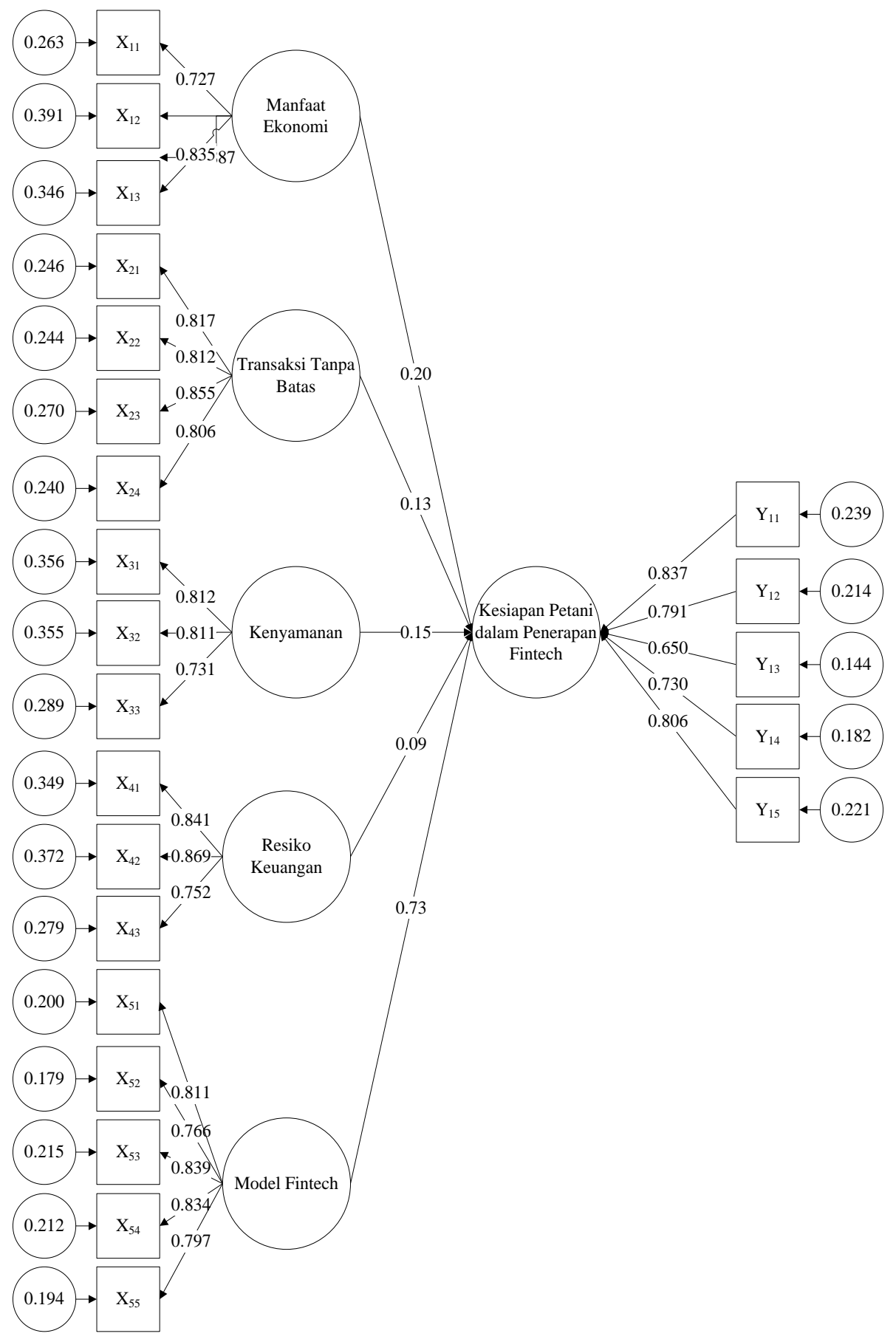

Figure 1 - Research path analysis results

Unlimited transactions did not affect farmers' readiness in implementing fintech. It was presented in Table 9 that the P-value of the unlimited transaction variable was $0.074>0.05$. This insignificant $p$-value indicated that the unlimited transaction variable did not affect the farmers' readiness in applying fintech. According to what happened in the field, many respondents were unable to use internet but their children could use it. So, in the unlimited transactions variable, there was an indication that the respondents actually wanted to apply fintech but was constrained by the lack of knowledge in using internet because they mostly graduated from elementary school (SD). In addition, the respondents stated that continuous assistance in using technology was needed. So, due to the limited knowledge, the 
respondents were not ready yet to apply fintech in terms of unlimited transactions. Therefore, unlimited transactions in this study did not significantly affect farmers' readiness in applying fintech.

In this study, the convenience variable had positive and significant impacts on farmers' readiness in applying fintech. This showed that the more comfortable the offer given by fintech, the readiness of farmers in applying fintech would also increase. The value of convenience impact toward farmers' readiness in applying fintech was 0.15 or $15 \%$ with significant level of $0.049<0.05$. It reported that, the convenience had an effect of 0.15 or $15 \%$ on farmers' readiness in applying fintech, while the other $86 \%$ had an impact on other variables.

In this study, financial risks had not significantly affected the readiness of farmers in applying fintech. It was seen from the p-value in Table 9 that showed no financial risk variables affected the readiness of farmers in implementing fintech because the $p$-value was 0173> 0.05, so it was insignificant. According to what happened in the field, the respondents considered the financial risk borne by the investor to be very helpful, but they agreed that there was fear because it was a debt that must be paid. But, obviously, age had an impact on this. While the respondents acknowledged that it was very beneficial, but it was still a debt that had to be paid, so they were afraid to take the debt.

Model Fintech Offered in this study had positive and significant impacts on farmers' readiness in applying fintech. It indicated that the fintech models provided good benefits and increased farmers' readiness in applying fintech. Fintech model had a major impact at 0.73 with a significance level of $<0.001$. This value showed that fintech model contributed $73 \%$ impact to the farmers' readiness in applying fintech, while the other $27 \%$ was influenced by other variables.

In this study, analyzed fintech model was Peer to Peer Lending (P2P) model. According to Wijaya, P2P Lending (2016) was a technology platform that brought digital borrowers (UKM) or individuals in need of capital to lenders who expect competitive return. In this study, farmers preferred to borrow and market individually because they did not find it difficult to restore loan and collect money from some people According to Nizar (2017), peer to peer consumer lending was a platform that provided consumers with direct loans to individual borrowers.

\section{CONCLUSION AND SUGGESTIONS}

Based on research findings and discussions on the farmers' readiness level in applying fintech of rice farmers in Malang on agribusiness capital and marketing activities. Fintech application in Indonesia has been rapidly developed since 2016. According to the data, in Indonesia fintech was mostly implemented for payment and lending. Besides that, the farmers are ready in fintech application if the offer gives some economic benefits in order to provide benefits for the farmers, convenience in transaction, and appropriate model in fintech specifically Peer to Peer (P2P) lending. The farmers' readiness can be seen from path coefficient values in the amount of $20 \%, 13 \%, 15 \%, 9 \%$ and $73 \%$ with significant values are $0.012,0.074,0.049,0.173$ and $<0.001$ for economic benefits, unlimited transactions, convenience, financial risk and fintech model offered. In addition, the fintech model that farmers in Malang Regency needed is Peer to Peer (P2P) Lending that defined as individual lending and marketing. It is supported by data showing that $87 \%$ of rice farmers in Singosari Regency prefer P2P lending.

Based on the conclusions, the suggestions can be submitted in this study are: Firstly, the company engaged in fintech is expected to offer services that provide economic benefits and convenience in transaction using fintech in order to make easier for farmers in applying fintech especially for rice farmers in Singosari Regency. In addition, the fintech model that ready to implement is Peer to Peer (P2P) lending. Secondly, Agricultural extension agent can help to assist farmers during fintech application by using both website platform and mobile phone application to well-realized the transfer of fintech knowledge and technology. 


\section{REFERENCES}

1. Amanah, S., \& Tjitropranoto, P. (2018). Tingkat Adopsi Good Agricultural Practices Budidaya Kopi Arabika Gayo oleh Petani di Kabupaten Aceh Tengah. Jurnal Penyuluhan, 14(2), 308-323.

2. Andriani, R., Kusumo, B., Rasmikayati, E., Mukti, G. W., Fatimah, S., \& Saefudin, B. R. (2018). Faktor-Faktor Yang Mempengaruhi Keputusan Petani Mangga Dalam Menggunakan Teknologi Off Season Di Kabupaten Cirebon. 4(1), 57-69.

3. Fintechnews Singapore. (2018). Fintech Landscape Report Indonesia (Issue May). World Bank the Association for internet service providers Indonesia and we are social.

4. Freedman. (2006). Introduction to Financial Technology. Academic Press.

5. Hapsari, S. F. (2018). Faktor-Faktor Yang Menentukan Keputusan Pemberian Kredit Usaha Kecil and Menengah (UKM) Pada Lembaga Pembiayaan Islamic Peer to Peer Lending.

6. Haryani, D. and T. M. (2013). Kajian Analisis Margin Pemasaran And Integrasi Pasar Gabah / Beras Di Provinsi Banten Abstrak. Buletin IKATAN, 3(1), 1-14.

7. Linawarti, A. (2015). Analisis saluran tataniaga beras di Wilayah Kecamatan Singosari Kabupaten Malang. Jesp, 7(1), 20-30. https://doi.org/2086-1575

8. Mulyaqin, T., \& Haryani, D. (2015). Aksesibilitas Petani Padi Sawah Terhadap Sumber Permodalan and Faktor-Faktor yang Mempengaruhinya di Provinsi Banten. Buletin IKATAN, 3(2), 26-28.

9. Muzdalifa, I., Rahma, I. A., \& Novalia, B. G. (2018). Peran Fintech dalam Meningkatkan Keuangan Inklusif pada UMKM di Indonesia (Pendekatan Keuangan Syariah. Jurnal Masharif Al-Syariah: Jurnaal Ekonomi and Perbankan Syariah, 3(1).

10. Nizar, M. A. (2017). Teknologi keuangan (Fintech): Konsep and implementasinya di Indonesia. Warta Fiskal, 5(December 2017), 5-13.

11. Ryu, H. S. (2018). What makes users willing or hesitant to use Fintech?: the moderating effect of user type. Industrial Management and Data Systems, 118(3), 541-569. https://doi.org/10.1108/IMDS-07-2017-0325

12. Soekartawi. (2005). Prinsip Dasar Komunikasi Pertanian. UI-Press.

13. Solimun, Fernandes, A. R. ., \& Nurjannah. (2017). Metode Statistika Multivariat Permodelan Persamaan Struktural (SEM) Pendekatan WarpPLS (Ketiga). UB Press.

14. Stern, C., Makinen, M., \& Qian, Z. (2017). FinTechs in China - with a special focus on peer to peer lending. Journal of Chinese Economic and Foreign Trade Studies, 10(3), 215-228. https://doi.org/10.1108/JCEFTS-06-2017-0015

15. Stewart, H., \& Jürjens, J. (2017). Information security management and the human aspect in organizations. Information and Computer Security, 25(5), 494-534. https://doi.org/10.1108/ICS-07-2016-0054

16. Sunarminto, B. H. (2015). Pertanian Terpadu untuk Mendukung Kedaulatan Pangan Nasional (Kedua) (II). Gadjah Mada University Press. https://books.google.co.id/books?id=atBWDwAAQBAJ\&pg=PA27\&dq=kesejahteraan+pet ani+adalah\&hl=id\&sa=X\&ved=0ahUKEwja4Ov6mq_eAhVObnOKHfpJBxcQ6AEIPzAE\#v= onepage \&q=kesejahteraan petani adalah\&f=false

17. Wang, J. (2018). From aperture satellite to "Internet finance": Institutionalization of ICTs in China's financial sector since 1991. Telecommunications Policy, 42(7), 566-574. https://doi.org/10.1016/j.telpol.2018.04.004

18. Wijaya, R. (2016). P2P Lending: Wujud Baru Inklusi Keuangan. Fintech Indonesia, 1-4. 